\title{
Peptide nucleic acid-DNA decoy chimeras targeting NF- $\kappa$ B transcription factors: Induction of apoptosis in human primary osteoclasts
}

\author{
LETIZIA PENOLAZZI ${ }^{1}$, MONICA BORGATTI ${ }^{2}$, ELISABETTA LAMBERTINI ${ }^{1}$, CARLO MISCHIATI $^{2,3}$, \\ ALESSIA FINOTTI $^{1}$, ALESSANDRA ROMANELLI ${ }^{3}$, MICHELE SAVIANO $^{3}$, \\ CARLO PEDONE $^{3}$, ROBERTA PIVA $^{1}$ and ROBERTO GAMBARI ${ }^{1,2,3}$

\begin{abstract}
${ }^{1}$ Department of Biochemistry and Molecular Biology, ${ }^{2}$ Laboratory for the Development of Pharmacological and Pharmacogenomic Treatment of Thalassemia, Biotechnology Center, ${ }^{3}$ Interdisciplinary Center for the Study of Inflammation, University of Ferrara, Ferrara; ${ }^{4}$ Institute of Biostructures and Bioimaging, CNR, Napoli, Italy
\end{abstract}

Received March 12, 2004; Accepted April 22, 2004

\begin{abstract}
Peptide nucleic acids (PNAs) are DNA mimics constituted by a pseudopeptide backbone composed of N-(2aminoethyl)glycine units. PNAs hybridize with high affinity to complementary sequences of single-stranded RNA and DNA, forming Watson-Crick double helices and are resistant to both nucleases and proteases. While applications of PNAs as antisense and antigene molecules have been described, PNA/ DNA and PNA/PNA hybrids are not useful for transcription factor decoy (TFD) pharmacotherapy. By contrast, PNADNA-PNA (PDP) chimeras, constituted of sequential PNA, DNA and PNA stretches, are potent decoy molecules in vitro. Interestingly, PDP-based decoys a) are more soluble than PNAs, b) are more resistant than synthetic oligonucleotides to enzymatic activity present in cellular extracts and serum and c) can be delivered with liposomes. In the present study we demonstrated that double-stranded PNA-DNA-PNA chimeras targeting $\mathrm{NF}-\kappa \mathrm{B}$ transcription factors induce
\end{abstract}

Correspondence to: Dr Roberto Gambari, Department of Biochemistry and Molecular Biology, University of Ferrara, Via L. Borsari no. 46, I-44100 Ferrara, Italy

E-mail: gam@unife.it

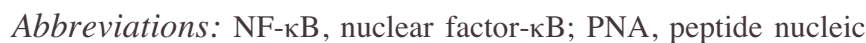
acids; PDP, PNA-DNA-PNA chimera; HATU, O-(7-azabenzotriazol1-yl)-1,1,3,3-tetramethyl luronium hexafluorophosphate; DIPEA, $\mathrm{N}, \mathrm{N}^{\prime}$-diisopropylcarbodiimide; OCs, osteoclasts; EMSA, electrophoretic mobility shift assay; TFD, transcription factor decoy; ODN, oligodeoxyribonucleotide; RANKL, receptor activator of nuclear factor- $\kappa \mathrm{B}$ ligand; M-CSF, macrophage colony-stimulating factor; PTH, parathyroid hormone; PBMC, peripheral blood mononuclear cells; TRAP, tartrate-resistant acid phosphatase; PC, phosphatidylcholine; DOTAP, N[-1-(2,3 dioleyloxy)propyl]-NNN-trimethylammonium methylsulfate

Key words: human osteoclasts, apoptosis, nuclear factor-кВ, transcription factor decoy, non-viral gene therapy, peptide nucleic acids, PNA-DNA chimeras apoptosis of human primary osteoclasts. Our data suggest that PDP-based induction of osteoclast apoptosis could be a therapeutic approach for disorders in which bone resorption is inappropriately excessive.

\section{Introduction}

The nuclear transcription factors belonging to the NF-kappaB $(\mathrm{NF}-\kappa \mathrm{B})$ superfamily are involved in several normal biological processes, as well as in human pathologies (1-4). For instance, the involvement of NF-кB in inflammation is well known, as well as the requirement of $\mathrm{NF}-\mathrm{\kappa B}$ activity in viral infection $(5,6)$. Therefore, molecular biology approaches aimed at the control of NF- $\mathrm{KB}$ activity have been in the past objects of several investigations (7-11).

Among non-viral gene therapy strategies able to inhibit or even block NF-кB activity, the transcription factor decoy (TFD) approach (12-14) should be taken into consideration, since NF-кB decoys have been recently used in several preclinical studies and proven to be active in several experimental systems (15-20). For instance, Ogushi et al (21) recently assessed the efficacy of in vivo transfer of synthetic TFD oligodeoxyribonucleotides (ODN) against NF- $\mathrm{KB}$ as a therapeutic strategy for treating endotoxin-induced fetal liver injury. NF-кB decoys were preferentially transferred to Kupffer cells, and activation of NF- $\mathrm{KB}$ was suppressed, leading to decreased inflammatory cytokine production. As a result, the massive necrosis observed in the control mice was dramatically attenuated and the survival rate improved (19). In addition, decoy ODNs were demonstrated to be useful to inhibit tumor cell growth and invasion $(20,22)$, as anti-inflammatory agents $(23,24)$, in myocardial preservation $(25-28)$, in cerebral angiopathy (29).

These decoy activities against $\mathrm{NF}-\kappa \mathrm{B}$ were achieved by using as decoy molecules synthetic oligonucleotides carrying $\mathrm{NF}-\kappa \mathrm{B}$ specific cis-elements. Unfortunately, synthetic ODNs are not stable in vivo or ex vivo and, therefore, should be extensively modified in order to be used (15,30-35).

In recent reports, we have proposed peptide nucleic acids (PNAs) as alternative reagents in experiments aimed at the 
control of gene expression involving the TFD approach (7,36-38). In PNAs, the pseudopeptide backbone is composed of N-(2-aminoethyl)glycine units $(39,40)$. PNAs hybridize with high affinity to complementary sequences of single-stranded RNA and DNA, forming Watson-Crick double helices (41) and are resistant to both nucleases and proteases (42). Even without considering studies on effects on cultured cells, Romanelli et al (7) demonstrated, for the first time, that PNADNA-PNA (PDP) chimeras mimicking the NF- $\kappa \mathrm{B}$ binding sites are capable of stable interaction with both purified NF-kB p52 and p50, as well as nuclear factors from B-lymphoid cells. This highly interesting feature of PDP chimeras was confirmed studying molecules carrying the binding sites for other transcription factors, such as $\mathrm{Sp} 1$ (38).

In agreement with these reports, we concluded that PNA-DNA-PNA chimeras deserve to be analysed for biological activity, in order to propose these molecules for the development of potential agents for a decoy approach in gene therapy.

In this respect, osteoclasts (OCs) are a very useful experimental system (43). In fact, proteins belonging to the $\mathrm{NF}-\kappa \mathrm{B}$ superfamily are involved in osteoclast formation, playing a very important role for both differentiation of osteoclast precursors and survival of mature osteoclasts. In this respect, targeting of NF- $\mathrm{KB}$ transcription factor could be of great interest (44-48). In a recent study, we examined the effects of decoy DNA/DNA molecules targeting NF- $\mathrm{\kappa B}$ on apoptosis of human osteoclasts, with the aim to interfere with the pathway regulating osteoclast differentiation and programmed cell death (49).

The aim of the present study was to verify whether PNADNA-PNA chimeras mimicking the binding site recognized by $\mathrm{NF}-\kappa \mathrm{B}$ are able to induce apoptosis of primary human osteoclasts. To this aim, a mixture of receptor activator of $\mathrm{NF}-\kappa \mathrm{B}$ ligand (RANKL), macrophage colony-stimulating factor (M-CSF) and parathyroid hormone (PTH) to prepare human OCs from peripheral blood cells was used. Then, transfection of osteoclasts with the decoy molecules based on PNA-DNAPNA chimeras and targeting $\mathrm{NF}-\kappa \mathrm{B}$ was performed.

\section{Materials and methods}

Synthetic oligonucleotides and production of $N F-\kappa B P N A$ DNA-PNA chimeras. The synthetic oligonucleotides used in this study were purchased from Sigma (St. Louis, MO, USA). PNA monomers for production of PNA-DNA chimeras were synthesized in the laboratories of Professor J.H. van Boom (50) (Leiden Institute of Chemistry, Gorlaeus Laboratories, Leiden University, The Netherlands); DNA monomers were obtained from Perseptive Biosystems. Methanol (Rathburn, HPLC grade) was stored over molecular sieves ( $3 \AA$ ) and used without other purification. All the other solvents (Biosolve DNA synthesis grade) were used as received. Automatized synthesis of the chimeras was performed on a Pharmacia Gene Assembler, using highly cross-linked polystyrene (loading 26-28 $\mu \mathrm{mol} / \mathrm{g}$ ) as the solid support on a $1-\mu \mathrm{mol}$ scale, as reported elsewhere (7). After the last elongation step, the oligomers were cleaved from the solid support and deprotected by treatment with $1.5 \mathrm{ml}$ methanolic ammonia, at $50^{\circ} \mathrm{C}$ for $16 \mathrm{~h}$. The samples were filtered and then purified by RP-HPLC on a LiChrosphere 100
RP-18 endcapped column $(4 \times 250 \mathrm{~mm})$ on a Jasco HPLC system. Gradient elution was performed at $40^{\circ}$ building up gradient starting with buffer A $(50 \mathrm{mM}$ triethylammonium acetate in water) and applying buffer B (50 mM triethylammonium acetate in acetonitrile/water, 1/1, v/v), with a flow rate of $1 \mathrm{ml} / \mathrm{min}$. Chimera 1 : HPLC purity $100 \%, \mathrm{t}_{\mathrm{R}}=$ $18 \mathrm{~min}$ (gradient $3-20 \% \mathrm{~B}$ in $25 \mathrm{~min}$ ); chimera 2: HPLC purity $100 \%, \mathrm{t}_{\mathrm{R}}=16 \mathrm{~min}$ (gradient $5-25 \% \mathrm{~B}$ in $25 \mathrm{~min}$ ). HPLC-MS analysis was carried out on a Jasco LCMS system equipped with a LiChrosphere 100 RP-18 endcapped column (4x250 mm) using a gradient of acetonitrile in $10 \mathrm{mM}$ ammonium acetate buffer with mass detection on a PerkinElmer Sciex API 165 equipped with an Electrospray Interface (ESI). Chimera 1: $\mathrm{t}_{\mathrm{R}}=7 \mathrm{~min}$ (gradient $5-20 \%$ acetonitrile in $29 \mathrm{~min})$; ESI-MS: $[\mathrm{M}+4 \mathrm{H}]^{4+}=1438.2,[\mathrm{M}+5 \mathrm{H}]^{5+}=1150.5$, calcd. for $\mathrm{C}_{193} \mathrm{H}_{245} \mathrm{~N}_{90} \mathrm{O}_{95} \mathrm{P}_{13}$ 5748.26. Chimera 2: $\mathrm{t}_{\mathrm{R}}=8 \mathrm{~min}$ (gradient $0-20 \%$ acetonitrile in $20 \mathrm{~min}$ ); ESI-MS: $[\mathrm{M}+4 \mathrm{H}]^{4+}=$ 1443.6, $[\mathrm{M}+5 \mathrm{H}]^{5+}=1154.9$, calcd. for $\mathrm{C}_{194} \mathrm{H}_{247} \mathrm{~N}_{86} \mathrm{O}_{99} \mathrm{P}_{13}$ 5770.26 .

\section{Sequences: Gly-ccg-5'TGGAAAGTCCCCA ${ }^{3}$-gcg-Ac 1 Gly-cgc-5'TGGGGACTTTCCA ${ }^{3}$ '-cgg-Ac 2}

Electrophoretic mobility shift assay. The electrophoretic mobility shift assay (EMSA) $(38,51)$ was performed by using the double-stranded synthetic oligonucleotides mimicking $\mathrm{NF}-\kappa \mathrm{B}$ binding sites (the nucleotide sequences are reported in Fig. 1). The target molecules were 5'-end-labelled using $\left[\gamma^{-32} \mathrm{P}\right] \mathrm{ATP}$ and T4 polynucleotide kinase (MBI Fermentas, Italy) in the case of DNA/DNA and DNA/PDP (36). [ $\left.{ }^{32} \mathrm{P}\right]-$ labelled PDP/PDP molecules were produced by nick-translation, using low concentration of DNase and $\left[\gamma^{-32} \mathrm{P}\right] \mathrm{dCTP}(36)$. Binding reactions were set up as described elsewhere (7) in a total volume of $25 \mu \mathrm{l}$ containing buffer $\mathrm{TF}+5 \%$ glycerol, $1 \mathrm{mM}$ DTT, $10 \mathrm{ng}$ of human NF-кB p52 protein (Promega Corp., Madison, WI) or $1 \mu \mathrm{g}$ of crude nuclear extracts from B-lymphoid Raji and human leukemic K562 cells $(7,38)$ and $0.25 \mathrm{ng}$ of [ $\left.{ }^{32} \mathrm{P}\right]$-labelled oligonucleotides. After $30 \mathrm{~min}$ binding at room temperature, the samples were electrophoresed at constant voltage $(200 \mathrm{~V})$ under low ionic strength conditions $(0.25 \mathrm{X}$ TBE buffer $=22 \mathrm{mM}$ Tris-borate, $0.4 \mathrm{mM}$ EDTA $)$ on $6 \%$ polyacrylamide gels. Gels were dried and subjected to standard autoradiographic procedures (36). In competition experiments, the competitor molecules carrying NF- $\mathrm{BB}$ binding sites (DNA/DNA, DNA/PDP, PDP/DNA and PDP/PDP) were preincubated for 20 min with purified NF-кB p52 protein before the addition of labelled target DNA. The nucleotide sequences of competitor double-stranded target DNAs used as controls were: 5'-TAA TAT GTA AAA ACA TT-3' (sense strand, NF-IL2A) and 5'-CAC TTG ATA ACA GAA AGT GAT AAC TCT-3' (sense strand, GATA-1).

Liposome preparation. Egg phosphatidyl choline was purchased from Lipid Products (Surrey, England). Tetralysinecholesterol ( $\mathrm{Lys}_{4}$-Chol) was a generous gift of Professor Marastoni (Department of Pharmaceutical Sciences, University of Ferrara). Positively charged liposomes were produced by a protocol based on reverse phase evaporation followed by extrusion of the liposome suspension through polycarbonate filters with homogeneous pore size $(36,52)$. Liposomes were 

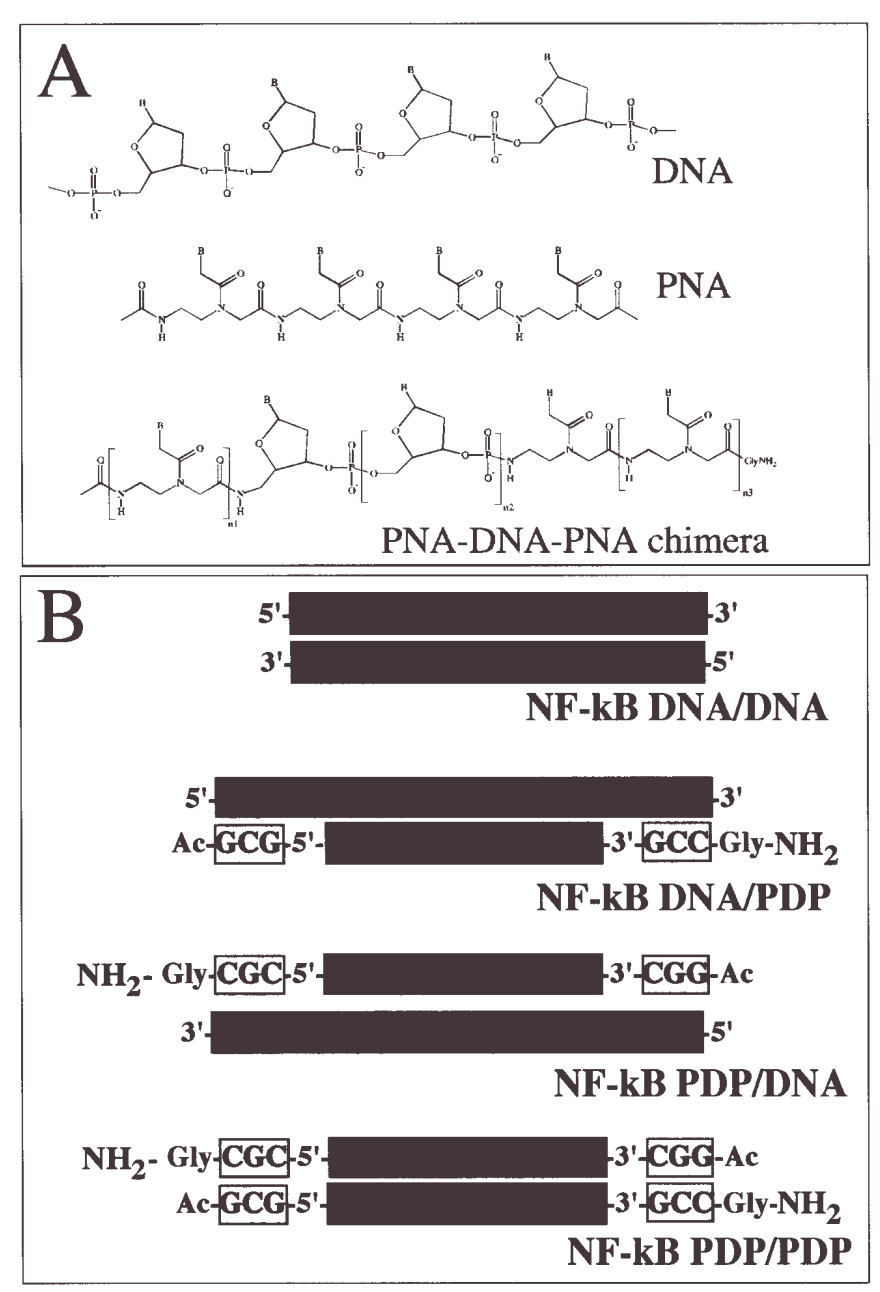

Figure 1. (A), General structure of DNA (upper part of the panel), PNA (middle part of the panel) and PNA-DNA-PNA chimera (lower part of the panel). (B), Sequences of the decoy molecules used in the present study. DNA stretches are in green, PNA stretches are in yellow.

subjected to one extrusion cycle through two stacked $400 \mathrm{~nm}$ pore size filters followed by three extrusion cycles through two stacked $200 \mathrm{~nm}$ pore size membranes, in order to obtain unilamellar liposomes with a homogeneous size distribution. The complexation of PNA-DNA chimeras to liposomes was performed just before the analysis, simply mixing the target decoy molecules to 'preformed' cationic vesicles, employing increasing liposome concentrations, including those which were known to cause a full complexation of target DNA/DNA hybrids (36-38). The verification of the obtained complexation of NF-кB DNA/DNA, DNA/PDP and PDP/PDP hybrids to liposomal formulations was reached following electrophoresis through an agarose gel and autoradiographic procedure (in the case of DNA/DNA or DNA/PDP) or staining with ethidium bromide (in the case of PDP/PDP molecules).

Resistance of decoy molecules. The resistance of [ $\left.{ }^{32} \mathrm{P}\right]$-labelled DNA/DNA and DNA/PDP target molecules was evaluated as follows: the decoy molecules were incubated without or with different concentrations (2-25 $\mu \mathrm{g} /$ reaction) of $\mathrm{Lys}_{4}$-Chol for $30 \mathrm{~min}$ at room temperature and then serum (fetal calf serum, Eurobio, France; $30 \mathrm{~g} / 1$ protein concentration) was added ( $3 \mu \mathrm{l} /$ reaction). After overnight incubation, the reactions were phenol-extracted, ethanol-precipitated, electrophoresed through a polyacrylamide gel and autoradiography was performed. Disappearance of the decoy molecule was considered as an evidence of degradation (37).

Culture of human primary OCs. Human OCs were prepared as reported by Matsuzaki et al (53) with slight modifications. Briefly, peripheral blood was collected from healthy normal volunteers after informed consent. Mononuclear cells (PBMCs) were prepared from diluted peripheral blood (1:2 in Hanks' balanced salt solution), which was layered over Histopaque 1077 (Sigma) solution, centrifuged (400 g), washed and resuspended in D-MEM/10\% FCS. $3 \times 10^{6} \mathrm{PBMCs} / \mathrm{cm}^{2}$ were plated in 24-well plates or in chamber slides and allowed to settled for $2 \mathrm{~h}$; wells were then rinsed to remove non-adherent cells. Monocytes were maintained at $37^{\circ} \mathrm{C}$, in $5 \% \mathrm{CO}_{2}$, in medium supplemented with $10 \%$ FCS and cultured for 14 days in the presence of human M-CSF (25 ng/ml), RANKL (30 ng/ $\mathrm{ml}$ ) and $10^{-7} \mathrm{M}$ PHT. Culture media were replenished with fresh media every 3-4 days. Cells were used for the described experiments when mature multinuclear cells were predominant in the cultures.

Tartrate-resistant acid phosphatase (TRAP) staining and immunocytochemistry analysis. TRAP staining of the cells was performed as reported by Villanova et al (54). Cells were fixed in $3 \%$ paraformaldehyde with $0.1 \mathrm{M}$ cacodilic buffer, pH 7.2 (0.1 M sodium cacodilate, $0.0025 \% \mathrm{CaCl}_{2}$ ) for 15 min, exstensively washed in the same buffer, and stained for TRAP (Acid Phosphatase Kit no. 386-Sigma). After washing with distilled water and drying, mature TRAP positive multinucleated cells containing more than three nuclei were counted as osteoclasts. Immunocytochemistry analysis was performed employing the streptavidin-biotin method using Ultraystain Polyvalent-HRP Immunostaining Kit (Ylem, Rome, Italy). OCs cells grown in multichamber slides were fixed in $100 \%$ cold methanol, and permeabilized with (v/v) Triton X-100 (Sigma) in TBS (Tris-buffered saline). Cells were incubated in $3 \% \mathrm{H}_{2} \mathrm{O}_{2}$ and blocked with Super Block reagent (Ultraystain Polyvalent-HRP Immunostaining Kit). After the reaction with the primary antibodies, the rabbit polyclonal antibody of human origin (Santa Cruz Biotech, Santa Cruz, CA, USA) against MMP9 was used according to the manufacturer's protocols, at 1:500 dilution; incubation was carried out at $4^{\circ} \mathrm{C}$ for $16 \mathrm{~h}$. Cells were then incubated at room temperature with anti-polyvalent biotinylated antibody (Ultraystain Polyvalent-HRP Immunostaining Kit). After rinsing in TBS, Streptavidin HRP (Ultraystain PolyvalentHRP Immunostaining Kit) was applied, followed by the addition of substrate-chromogen mix (AEC Cromogeno Kit, Ylem). After washing, cells were mounted in glycerol/TBS 9:1 and observed using a Leitz microscope.

DNA transfection and decoy experiments. Peripheral blood mononuclear cells (PBMCs), plated at the density of $3 \times 10^{6} / \mathrm{cm}^{2}$ in multichamber slides, as indicated, were transiently transfected with $0.5,1$ and $2 \mu \mathrm{g} / \mathrm{ml}$ of DNA/DNA, DNA/PDP, PDP/DNA and PDP/PDP complexed with $2.5,5$ and $10 \mu \mathrm{g}$ of PC:DOTAP, performing the decoy experiments with the protocol previously described $(55,56)$. 
Cytotoxicity studies. The cytoxicity effect of PC:DOTAP cationic liposomes complexed with scrambled oligonucleotide was determined on in vitro cultured human OCs cells. $3 \times 10^{6} / \mathrm{cm}^{2}$ PBMCs were plated in 96-well plates and, after 14 days, OCs were incubated with PC:DOTAP/DNA complex at different concentration $(0.15,0.3,1$ and $2 \mu \mathrm{g} / \mathrm{ml})$ for 3 days. Determinations of viable cells after DNA treatment were performed after colorimetric assay with MTT (Thiazolyl blue).

Measurement of apoptosis. After 14 days of cell culture and 2-4 days of decoy experiments, the cells were rinsed in 2x PBS solution and fixed for $25 \mathrm{~min}$ in $4 \%$ paraformaldehyde at room temperature. Apoptotic cells were detected by the DeadEnd Colorimetric Apoptosis Detection System (Promega) according to the manufacturer's instructions. Measurement of apoptosis was calculated as a percentage of apoptotic nuclei (dark brown nuclei) versus total nuclei of multinucleated TRAP positive cells, evaluated in three independent experiments.

Statistical analysis. Data are presented as the mean \pm SEM from at least three independent experiments. Statistical analysis was performed by one-way analysis of variance followed by the Student's t-test. A p-value $<0.001$ was considered statistically significant.

\section{Results}

Synthetic oligonucleotides and PNA-DNA-PNA chimeras. Fig. 1A shows the general structure of PNA-DNA-PNA chimeras (lower part of the panel), as compared to those of DNA (upper part of the panel) and PNA (middle part of the panel). Fig. 1B shows the sequences of the decoy molecules employed. Previously, we reported that PDP/PDP are powerful TFD molecules when used in in vitro assays employing EMSA (7).

The double-stranded PDP/DNA, DNA/PDP and PDP/PDP chimeras inhibit the interactions between $N F-\kappa B$ transcription factors and target DNA/DNA molecules. When $10 \mathrm{ng}$ of human $\mathrm{NF}-\kappa \mathrm{B}$ p50 proteins were incubated for $20 \mathrm{~min}$ in the presence of the $\left[{ }^{32} \mathrm{P}\right]$-labelled NF-кB DNA/DNA, DNA/PDP and PDP/PDP molecules, it appears that all of them are able to interact with this protein, although with different efficiency (Fig. 2A). This binding is specific, since is competed by addition of cold NF- $\kappa$ B DNA/DNA and DNA/PDP (Fig. 2A, lanes $a$ and $b$, and data not shown). Accordingly, the same cold double-stranded NF-кB PDP/PDP, PDP/DNA and DNA/PDP molecules are able to inhibit the interactions between crude unfractionated nuclear factors from B-lymphoid Raji cells and target [ $\left.{ }^{32} \mathrm{P}\right]$-labelled NF-кB DNA/DNA probe (Fig. 2B). The results obtained strongly suggest that, under these experimental conditions, the double-stranded decoy molecules based on PNA-DNA-PNA chimeras efficiently bind to NF-kB transcription factors. Furthermore, we demonstrated that addition of cold double-stranded PDP/PDP, PDP/DNA, and DNA/PDP molecules do not affect the binding of NF-IL2A and GATA-1 factors to the respective target [ $\left.{ }^{32} \mathrm{P}\right]$-labelled DNA/DNA probes (Fig. 2C). The experiment reported in Fig. 2C was performed using $\left[{ }^{32} \mathrm{P}\right]$-end labelled NF-IL2A and GATA-1 DNA-DNA target molecules and nuclear factors isolated from Raji and K562 cell lines, respectively. Similar

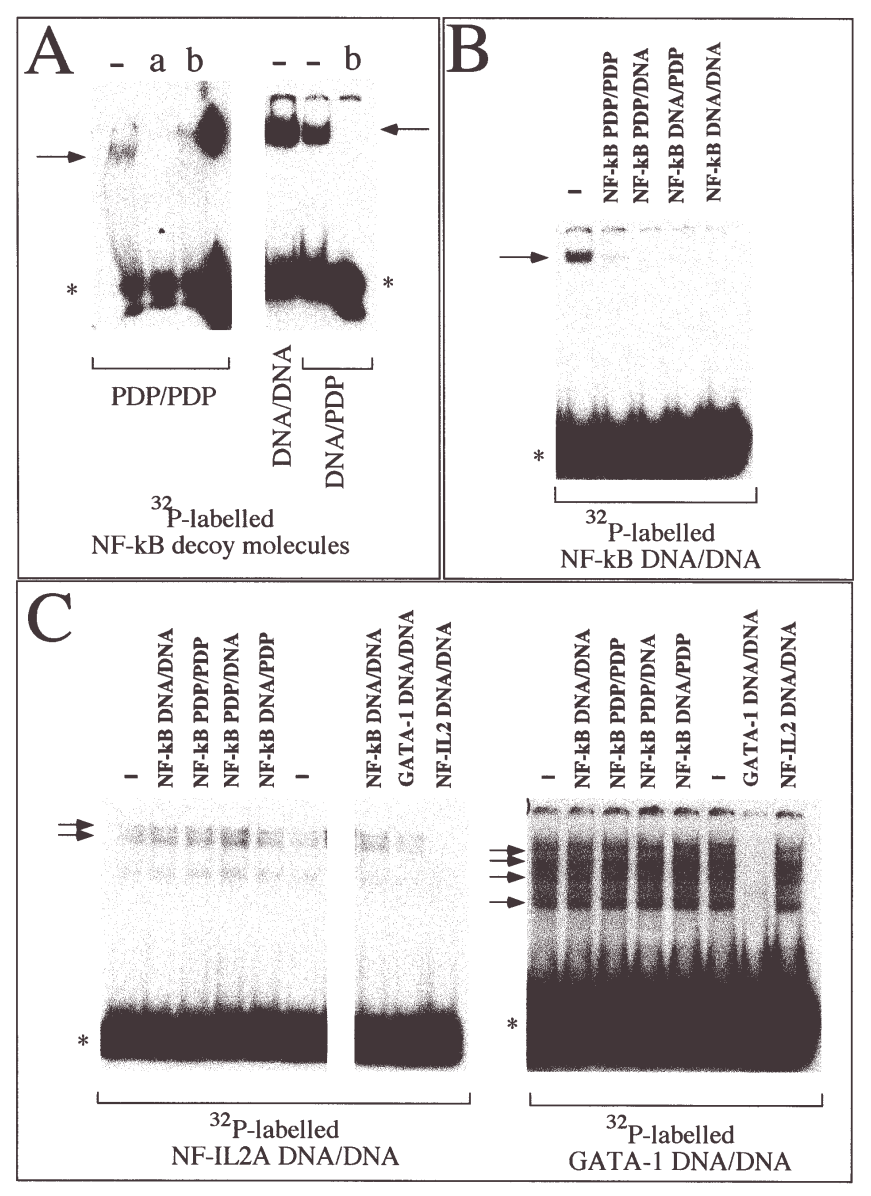

Figure 2. (A), Direct binding of $\left[{ }^{32} \mathrm{P}\right]$-labelled NF-кB PDP/PDP, DNA/DNA and DNA/PDP molecules to p50 NF- $\mathrm{B}$ factor. $\left[{ }^{32} \mathrm{P}\right]$-labelled $\mathrm{NF}-\kappa \mathrm{B}$ decoy molecules were incubated with p50 NF- $\mathrm{BB}$ nuclear factors in the absence (-) or in the presence of DNA/DNA (a) and DNA/PDP (b) cold competitors. (B and C), Effects of additions of $50 \mathrm{ng}$ of competitor molecules, as indicated, on the interactions of nuclear factors from human B-lymphoid Raji (B and left side of $\mathrm{C}$ ) or erythroleukemic $\mathrm{K} 562$ (C, right side) to [ $\left.{ }^{32} \mathrm{P}\right]$-labelled $\mathrm{NF}_{-\kappa} \mathrm{B}$ (B); NF-IL2A (C, left side) and GATA-1 (C, right side) DNA/DNA probes.

results were obtained using [ $\left.{ }^{32} \mathrm{P}\right]$-end labelled STAT-1 DNADNA target molecules (data not shown). Therefore, these results firmly establish that the effects of PNA-DNA chimeras are sequence-specific.

Effects of the NF-кB DNA/DNA decoy molecules on primary human osteoclasts. After 14 days of cell culture in the presence of RANKL, M-CSF and PTH, human OCs obtained from peripheral blood were analysed for the expression of the osteoclast-associated enzyme tartrate-resistant acid phosphatase (TRAP) and MMP9 (the scheme of the experiment is outlined in Fig. 3A). Fig. 3B shows representative examples of TRAP-positive and MMP9positive cells after 7, 14 and 21 days, demonstrating that OCs are obtained in these experimental conditions. Most of them were multinucleated and likely represent prefusion osteoclasts, since they also express the MMP9 osteoclast-associated antigen (46), being on the contrary negative to immunostaining with monoclonal antibody GSR1, recognizing the macrophage-associated antigen CD14, not expressed by osteoclasts (47) (data not shown).

The effects of the double-stranded decoy ODN targeting $\mathrm{NF}-\kappa \mathrm{B}$ were analyzed on isolated multinucleated cells in 


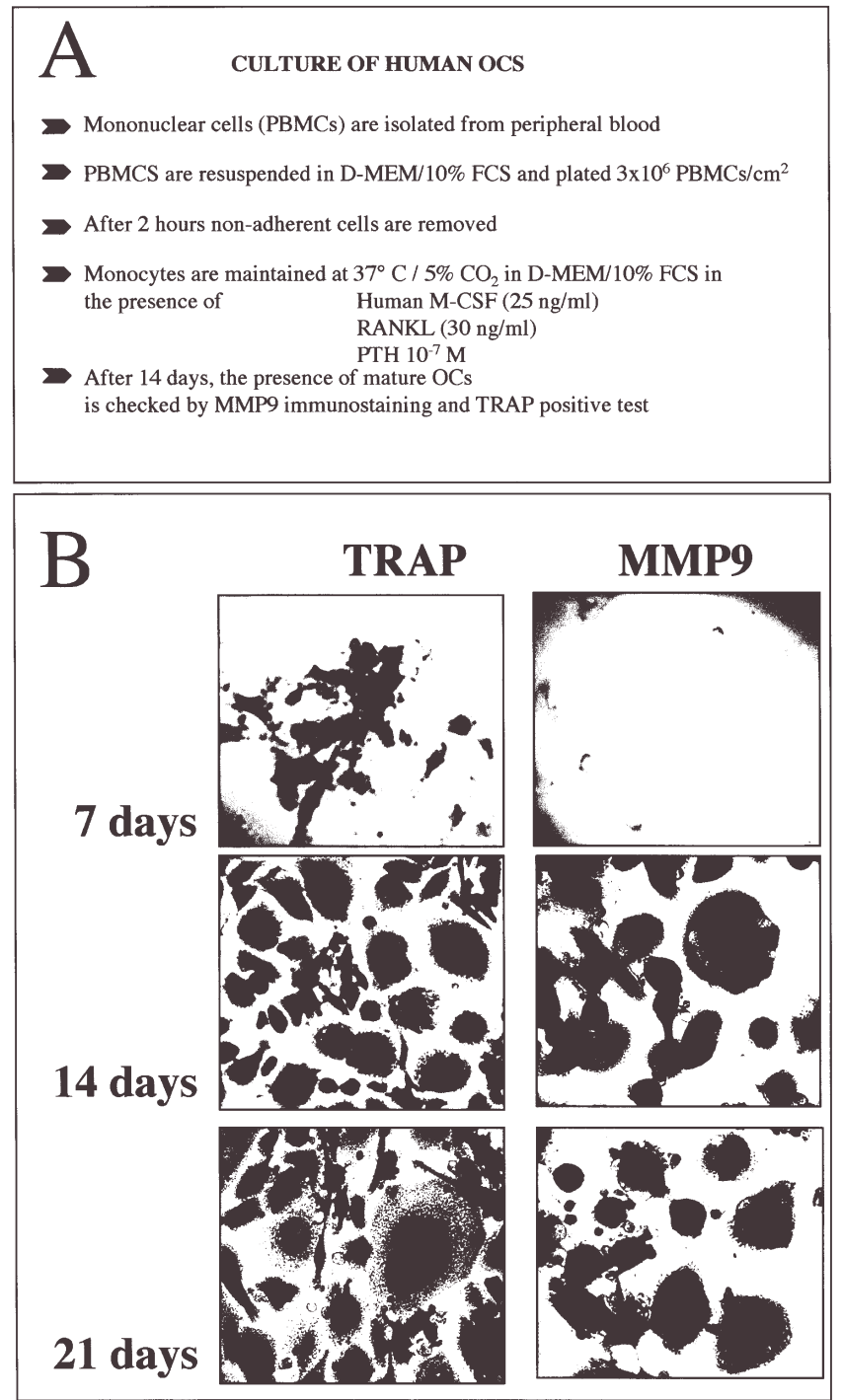

Figure 3. (A). Flow chart of the culture system employed for production of primary osteoclasts. (B), Primary osteoclast cultures, prepared as described in Materials and methods, were treated for 7, 14 and 21 days with $25 \mathrm{ng} / \mathrm{ml}$ $\mathrm{M}-\mathrm{CSF}+30 \mathrm{ng} / \mathrm{ml}$ RANKL and PTH $10^{-7} \mathrm{M}$ and subsequently stained for TRAP (left side of the panel) and MMP9 (right side of the panel). Multinucleated ( $>3$ nuclei), TRAP-positive cells were consistently obtained in different experiments. The TRAP ${ }^{+}$cells represent $5-10 \%$ of total number of cells and considered as mature osteoclasts.

terms of apoptosis. We treated primary OCs with the NF-кB HIV-1 decoy molecule complexed with PC:DOTAP cationic liposomes using DNA and lipid dosages previously determined in other cells types (56-58) to retain functional activity without affecting cell viability. Since data from literature indicate that a lipid formulation can display a differential toxicity on different cultured cells, a first set of experiments was addressed to investigate whether the employed liposomal formulations display cytotoxicity in osteoclasts. The adherent cells were treated with different amounts of cationic liposomes in combination with unrelated (scrambled) ODN, and viable cells were quantified by a colorimetric assay with Thiazolyl blue (MTT assay). Notably, treatment with $1 \mu \mathrm{g} / \mu \mathrm{l}$ of DNA/liposome complex failed to yield any cytotoxic effect on the total cell population and on osteoclasts, indicating that the conditions employed for the

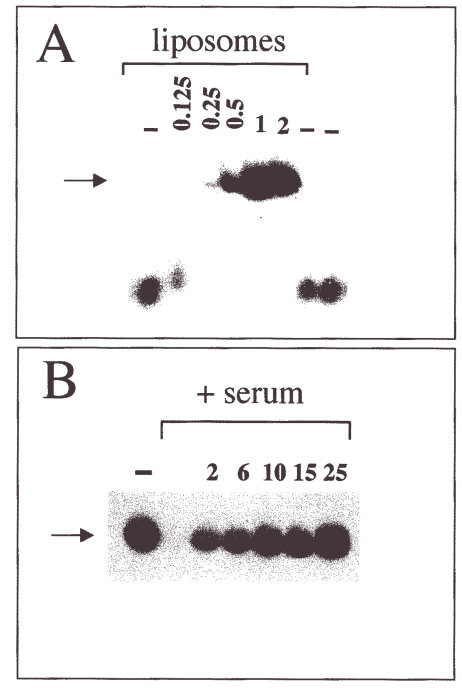

Figure 4. (A), Complexation of $\left[{ }^{32} \mathrm{P} \mid\right.$-labelled NF-KB DNA/PDP molecules to increasing amounts of $\mathrm{Lys}_{4} \mathrm{Chol}$ liposomes ( $\left.\mu \mathrm{g} / \mathrm{reaction}\right)$. (B), Protective effects of increasing amounts of $\mathrm{Lys}_{4} \mathrm{Chol}$ liposomes ( $\mu \mathrm{g} /$ reaction) on $\left[{ }^{32} \mathrm{P}\right]$ labelled NF-кB DNA/PDP molecules incubated in the presence of $3 \mu \mathrm{l} /$ reaction of serum.

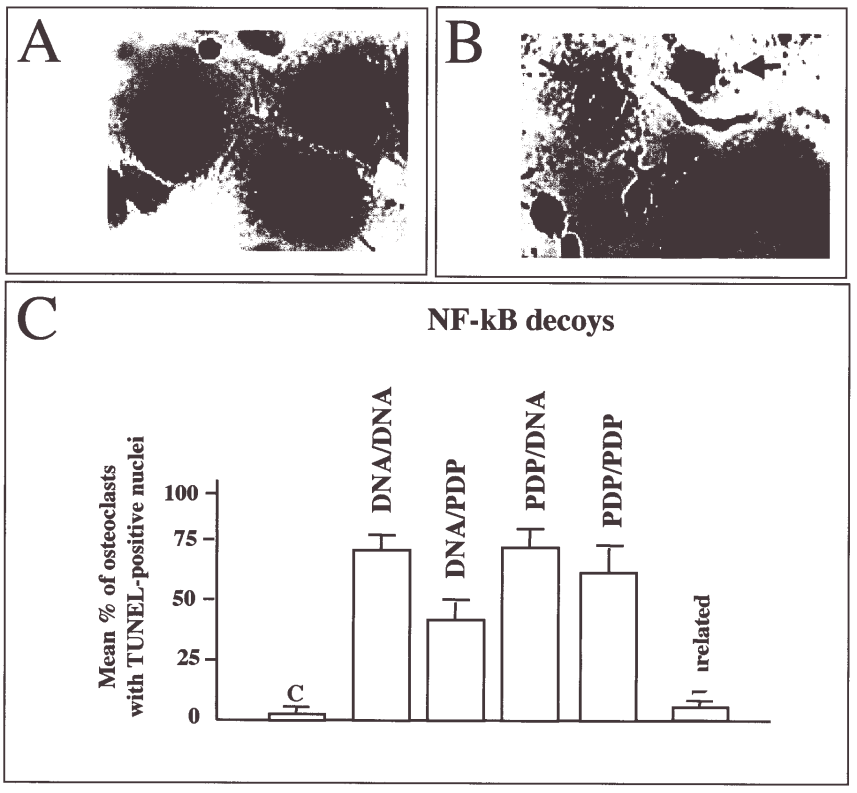

Figure 5. Effects of PNA-based decoy on apoptosis of human ostoclasts. (A and B), Detection of apoptosis by TUNEL assay in human osteoclast cells. Cells, cultured as described in legend to Fig. 3, were transiently transfected with $1 \mu \mathrm{g}$ of scrambled oligonucleotide (A) or $1 \mu \mathrm{g}$ of $\mathrm{NF}-\kappa \mathrm{B}$ decoy oligonucleotide (B), both complexed with cationic liposomes. Cells were then photographed at $\times 40$ magnification. Apoptotic osteoclasts are arrowed. (C), Primary osteoclasts were transiently transfected for $48 \mathrm{~h}$ with $1 \mu \mathrm{g}$ of NF- $\mathrm{B}$ DNA/DNA, DNA/PDP; PDP/DNA and PDP/PDP decoy molecules or double-stranded unrelated oligonucleotides, as indicated. The $\%$ mean \pm SEM of osteoclasts with TUNEL-positive nuclei is reported.

decoy approach did not decrease cell viability (data not shown).

Effects of the NF-кB DNA/DNA decoy molecules on PNADNA-PNA decoys on primary human osteoclasts. We first 
demonstrated that PDP-based decoy molecules are complexed with liposomes (see the representative experiment shown in Fig. 4A) and that this complexation protects these molecules from degradation when incubated in the presence of serum (see the representative experiment shown in Fig. 4B). The details of liposome complexation and protection from degradation in the presence of serum and cellular extracts have been reported by Borgatti et al (38).

Mature osteoclasts and TRAP-positive precursors were therefore treated with $1 \mu \mathrm{g} / \mu \mathrm{l}$ of the decoy molecules for $48 \mathrm{~h}$ and then subjected to analysis of apoptosis. Morphological analysis of NF-kB decoy-treated osteoclasts demonstrated cell retraction in comparison with unrelated ODN control-treated osteoclasts (see the representative experiment shown in Fig. 5A and B), indicative of apoptosis. Several nuclei showed morphological changes consistent with nuclear damage. Therefore, after treatment with the decoy against NF-кB on day 14 (when osteoclast differentiation was complete), a great change in cell survival of osteoclasts was observed.

To confirm apoptosis, TUNEL staining of fragmented DNA was performed. As shown in Fig. 5C NF-кB decoy caused programmed cell death at a very early stage with more than 13-fold increase in the percentage of apoptotic osteoclasts. In addition, the results obtained demonstrated that all the PDP-based decoy molecules were able to induce apoptosis of primary OCs.

\section{Discussion}

The main issue of this study was to verify whether PNA-DNAPNA (PDP) chimeras targeting NF- $\kappa \mathrm{B}$ transcription factors induce apoptosis of human primary osteoclasts. The results obtained firmly demonstrated that PDP chimeras against $\mathrm{NF}-\kappa \mathrm{B}$ are powerful inducers of apoptosis of human osteoclasts. This is the first observation of biological activity of these reagents, when administered to target cells.

In PNAs, the pseudopeptide backbone is composed of $\mathrm{N}$-(2-aminoethyl)glycine units $(40,59)$. PNAs hybridize with high affinity to complementary sequences of single-stranded RNA and DNA, forming Watson-Crick double helices $(39,41)$ and are resistant to both nucleases and proteases (42). However, PNA/DNA and PNA/PNA hybrids are not useful for applications in the transcription factor decoy (TFD) pharmacotherapy $(40,51,60)$. In this respect PDP-based decoys are of great interest since: a) PDP are more soluble than PNAs (40), b) PDP are more resistant than ODNs to enzymatic activity present in cellular extracts and serum (38) and c) PDP can be delivered with liposomes (36).

The effects of PDP-based NF-кB decoys are related to the involvement of this transcription factor on biological functions of OCs. Accumulating evidence indicates indeed that NF- $\mathrm{BB}$ is associated with activation of osteoclasts and is important for both differentiation of osteoclast precursors and survival of mature osteoclasts (46).

Even if further studies addressing a) the identification of candidate genes regulated by $\mathrm{NF}-\kappa \mathrm{B}$ important for osteoclast survival and b) the mechanisms by which NF- $\mathrm{KB}$ inhibition stimulates osteoclast apoptosis (including the detailed analysis of the effects of NF-кB decoys on all the pro-apoptotic and apoptosis-associated genes) are necessary, we suggest that the induction of apoptosis after NF-кB decoy treatment obtained in primary osteoclasts from peripheral blood, could be also obtained in other tissue environments and used in the control of bone formation. Accordingly, promotion of osteoclast apoptosis has become a very important therapeutic target for disorders in which bone resorption is inappropriately excessive.

The potent therapeutic agents employed at present, such as estrogen and aminobisphosphonates, have side effects that limit their systemic use.

Therefore, the development of a strategy based on nucleic acid drugs and analogues, such as described herein, may be of great interest for therapeutics optimized for both safety and efficacy.

\section{Acknowledgements}

The authors gratefully acknowledge Professor A. Teti, Department of Experimental Medicine, University of L'Aquila, L'Aquila, Italy, and Drs A. Taranta and S. Migliaccio, Department of Histology and Medical Embryology, University La Sapienza of Rome, Rome, Italy, for valuable theoretical and technical advice on human OCs culture. M.B. is supported by a fellowship from Associazione Veneta per la Lotta alla Talassemia (AVLT). E.L. is supported by a fellowship from Cassa di Risparmio di Cento. This work was supported by MURST-COFIN-2002, FIRB-2001, AIRC, Finalized Research funds (year 2001) from the Italian Ministry of Health and Associazione Veneta per la Lotta alla Talassemia (AVLT). Mr. Giuseppe Perretta is acknowledged for technical assistance. The authors thank Professor J.H. van Boom and J.C. Verhejien for giving the possibility of synthesizing the chimeras in their laboratory.

\section{References}

1. Tian B and Brasier AR: Identification of a nuclear factor kappa B-dependent gene network. Recent Prog Horm Res 58: 95-130, 2003.

2. Nakshatri H and Goulet RJ Jr: NF-kappaB and breast cancer. Curr Probl Cancer 26: 282-309, 2002.

3. Algul H, Adler G and Schmid RM: NF-kappaB/Rel transcriptional pathway: implications in pancreatic cancer. Int $\mathrm{J}$ Gastrointest Cancer 31: 71-78, 2002.

4. Gilmore TD: The Rel1/NF-kappa B/I kappa B signal transduction pathway and cancer. Cancer Treat Res 115: 241-265, 2003.

5. Liou HC: Regulation of the immune system by NF-kappaB and IkappaB. J Biochem Mol Biol 35: 537-546, 2002.

6. Kracht $\mathrm{M}$ and Saklatvala J: Transcriptional and post-transcriptional control of gene expression in inflammation. Cytokine 20: 91-106, 2002.

7. Romanelli A, Pedone C, Saviano M, Bianchi N, Borgatti M, Mischiati $\mathrm{C}$ and Gambari R: Molecular interactions with nuclear factor kappaB (NF-kappaB) transcription factors of a PNA-DNA chimera mimicking NF-kappaB binding sites. Eur J Biochem 68: 6066-6075, 2001.

8. Wright JG and Christman JW: The role of nuclear factor kappa B in the pathogenesis of pulmonary diseases: implications for therapy. Am J Respir Med 2: 211-219, 2003.

9. Young MR, Yang HS and Colburn NH: Promising molecular targets for cancer prevention: AP-1, NF-kappa B and Pdcd4. Trends Mol Med 9: 36-41, 2003.

10. Amit S and Ben-Neriah Y: NF-kappaB activation in cancer: a challenge for ubiquitination- and proteasome-based therapeutic approach. Semin Cancer Biol 13: 15-28, 2003.

11. Umezawa $\mathrm{K}$ and Chaicharoenpong $\mathrm{C}$ : Molecular design and biological activities of NF-kappaB inhibitors. Mol Cells 14: 163-167, 2002. 
12. Cho-Chung YS, Park YG, Nesterova M, Lee YN and Cho YS : CRE-decoy oligonucleotide-inhibition of gene expression and tumor growth. Mol Cell Biochem 212: 29-34, 2000.

13. Cooper JA Jr, Parks JM, Carcelen R, Kahlon SS, Sheffield M and Culbreth R: Attenuation of interleukin- 8 production by inhibiting nuclear factor-kappaB translocation using decoy oligonucleotides. Biochem Pharmacol 59: 605-613, 2000.

14. Piva R and Gambari R: Transcription factor decoy (TFD) in breast cancer research and treatment. Technol Cancer Res Treat 1: 405-416, 2002

15. Kozlov IA, Kubareva EA, Ivanovskaya MG and Shabarova ZA: Design of new reagents on the base of DNA duplexes for irreversible inhibition of transcription factor NF-kappa B. Antisense Nucleic Acid Drug Dev 7: 279-289, 1997.

16. Vos IH, Govers R, Grone HJ, Kleij L, Schurink M, De Weger RA, Goldschmeding R and Rabelink TJ: NFkappaB decoy oligodeoxynucleotides reduce monocyte infiltration in renal allografts. FASEB J 14: 815-822, 2000.

17. Bonham CA, Peng L, Liang X, Chen Z, Wang L, Ma L, Hackstein H, Robbins PD, Thomson AW, Fung JJ, Qian S and Lu L: Marked prolongation of cardiac allograft survival by dendritic cells genetically engineered with NF-kappa B oligodeoxyribonucleotide decoys and adenoviral vectors encoding CTLA4-Ig. J Immunol 169: 3382-3391, 2002.

18. Quan N, Ho E, La W, Tsai YH and Bray T: Administration of NF-kappaB decoy inhibits pancreatic activation of NF-kappaB and prevents diabetogenesis by alloxan in mice. FASEB J 15: 1616-1618, 2001

19. Nakamura H, Aoki M, Tamai K, Oishi M, Ogihara T, Kaneda Y and Morishita R: Prevention and regression of atopic dermatitis by ointment containing $\mathrm{NF}-\kappa \mathrm{B}$ decoy oligodeoxynucleotides in NC/Nga atopic mouse model. Gene Ther 9: 221-229, 2002.

20. Griesenbach U, Scheid P, Hillery E, De Martin R, Huang L, Geddes DM and Alton EW: Anti-inflammatory gene therapy directed at the airway epithelium. Gene Ther 7: 306-313, 2000 .

21. Ogushi I, Iimuro Y, Seki E, Son G, Hirano T, Hada T, Tsutsui H, Nakanishi K, Morishita R, Kaneda Y and Fujimoto J: Nuclear factor kappa B decoy oligodeoxynucleotides prevent endotoxininduced fatal liver failure in a murine model. Hepatology 38 335-344, 2003

22. Sharma HW, Perez JR, Higgins-Sochaski K, Hsiao R and Narayanan R: Transcription factor decoy approach to decipher the role of NF-kappa B in oncogenesis. Anticancer Res 16: 61-69, 1996.

23. Griesenbach U, Cassady RL, Cain RJ, DuBois RM, Geddes DM and Alton EW: Cytoplasmic deposition of NFkappaB decoy oligonucleotides is insufficient to inhibit bleomycin-induced pulmonary inflammation. Gene Ther 9: 1109-1115, 2002.

24. D'Acquisto F, Ialenti A, Ianaro A, Di Vaio R and Carnuccio R: Local administration of transcription factor decoy oligonucleotides to nuclear factor-kappaB prevents carrageenininduced inflammation in rat hind paw. Gene Ther 7: 1731-1737, 2000 .

25. Morishita R, Sugimoto T, Aoki M, Kida I, Tomita N Moriguchi A, Maeda K, Sawa Y, Kaneda Y, Higaki J and Ogihara T: In vivo transfection of cis element 'decoy' against nuclear factor-kappaB binding site prevents myocardial infarction. Nat Med 3: 894-899, 1997.

26. Tomita N, Morishita R, Tomita S, Yamamoto K, Aoki M, Matsushita H, Hayashi S, Higaki J and Ogihara T: Transcription factor decoy for nuclear factor-kappaB inhibits tumor necrosis factor-alpha-induced expression of interleukin- 6 and intracellular adhesion molecule-1 in endothelial cells. J Hypertens 16: 993-1000, 1998.

27. Sakaguchi T, Sawa Y, Fukushima N, Nishimura M, Ichikawa H, Kaneda Y and Matsuda H: A novel strategy of decoy transfection against nuclear factor-kappaB in myocardial preservation. Ann Thorac Surg 71: 624-629, 2001

28. Suzuki J, Morishita R, Amano J, Kaneda Y and Isobe M: Decoy against nuclear factor-kappa B attenuates myocardial cell infiltration and arterial neointimal formation in murine cardiac allografts. Gene Ther 7: 1847-1852, 2000.

29. Ueno T, Sawa Y, Kitagawa-Sakakida S, Nishimura M Morishita R, Kaneda Y, Kohmura E, Yoshimine T and Matsuda H: Nuclear factor-kappa B decoy attenuates neuronal damage after global brain ischemia: a future strategy for brain protection during circulatory arrest. J Thorac Cardiovasc Surg 122: 720-727, 2001.
30. Lim CS, Jabrane-Ferrat N, Fontes JD, Okamoto H, Garovoy MR, Peterlin BM and Hunt CA: Sequence-independent inhibition of RNA transcription by DNA dumbbells and other decoys. Nucleic Acids Res 25: 575-580, 1997.

31. Iwase R, Namba M, Yamaoka T and Murakami A: Gene regulation by decoy approach (I): synthesis and properties of photo-crosslinked oligonucleotides. Nucleic Acids Symp Ser 37: 203-204, 1997.

32. Yamashita J, Yoshimasa T, Arai H, Hiraoka J, Tayaya K, Miyamoto Y, Ogawa Y, Itoh H and Nakao K: Identification of cis-elements of the human endothelin-A receptor gene and inhibition of the gene expression by the decoy strategy. J Biol Chem 273: 15993-15999, 1998.

33. Clusel C, Meguenni S, Elias I, Vasseur M and Blumenfeld M: Inhibition of HSV-1 proliferation by decoy phosphodiester oligonucleotides containing ICP4 recognition sequences. Gene Expr 4: 301-309, 1995.

34. Morishita R, Gibbons GH, Horiuchi M, Ellison KE, Nakama M, Zhang L, Kaneda Y, Ogihara T and Dzau VJ: Potential for transcatheter application of antisense oligonucleotides for the treatment of vascular diseases. Proc Natl Acad Sci USA 92: 5855-5859, 1995

35. Uhlmann E, Peyman A and Will DW: Antisense: chemical modifications. In: Encyclopedia of Cancer. Bertino JR (ed). Vol. 1. Academic Press, San Diego, pp64-81, 1997.

36. Borgatti M, Breda L, Cortesi R, Nastruzzi C, Romanelli A, Saviano M, Bianchi N, Mischiati C, Pedone C and Gambari R: Cationic liposomes as delivery systems for double-stranded PNA-DNA chimeras exhibiting decoy activity against NFkappaB transcription factors. Biochem Pharmacol 64: 609-616, 2002.

37. Borgatti M, Romanelli A, Saviano M, Pedone C, Lampronti I, Breda L, Nastruzzi C, Bianchi N, Mischiati C and Gambari R: Resistance of decoy PNA-DNA chimeras to enzymatic degradation in cellular extracts and serum. Oncol Res 13: 279-287, 2003

38. Borgatti M, Lampronti I, Romanelli A, Pedone C, Saviano M, Bianchi N, Mischiati C and Gambari R: Transcription factor decoy molecules based on a peptide nucleic acid (PNA)-DNA chimera mimicking Sp1 binding sites. J Biol Chem 278: 7500-7509, 2003

39. Nielsen PE and Egholm M: An introduction to peptide nucleic acid. Curr Issues Mol Biol 1: 89-104, 1999

40. Gambari R: Peptide-nucleic acids (PNAs): a tool for the development of gene expression modifiers. Curr Pharm Des 7: 1839-1862, 2001 .

41. Egholm M, Buchardt O, Christensen L, Behrens C, Freier SM, Driver DA, Berg RH, Kim SK, Norden B and Nielsen PE: PNA hybridizes to complementary oligonucleotides obeying the Watson-Crick hydrogen-bonding rules. Nature 365: 566-568, 1993.

42. Demidov VV, Potaman VN, Frank-Kamenetskii MD, Egholm M, Buchard O, Sonnichsen SH and Nielsen PE: Stability of peptide nucleic acids in human serum and cellular extracts. Biochem Pharmacol 48: 1310-1313, 1994

43. Roodman GD: Advances in bone biology: the osteoclasts. Endocr Rev 17: 308-332, 1996.

44. Suda T, Nakamura I, Jimi E and Takahashi N: Regulation of osteoclasts function. J Bone Miner Res 12: 869-879, 1997.

45. Yang $\mathrm{X}$ and Karsenty G: Transcription factors in bone: developmental and pathological aspects. Trends Mol Med 8: 340-345, 2002.

46. Wei S, Teitelbaum SL, Wang MW and Ross FP: Receptor activator of nuclear factor-kappaB ligand activates nuclear factor-kappa B in osteoclast precursors. Endocrinology 142: 1290-1295, 2001

47. Wong BR, Josien R, Lee SY, Vologodskaia M, Steinman RM and Choi Y: The TRAF family of signal transducers mediates NF-kappaB activation by the TRANCE receptor. J Biol Chem 273: 28355-28359, 1998 .

48. Ozaki K, Takeda H, Iwahashi H, Kitano S and Hanazawa S: $\mathrm{NF}_{-\kappa \mathrm{B}}$ inhibitors stimulate apoptosis of rabbit mature osteoclasts and inhibit bone resorption by these cells. FEBS Lett 410: 297-300, 1997.

49. Penolazzi L, Lambertini E, Borgatti M, Piva R, Cozzani M, Giovannini I, Naccari R, Siciliani G and Gambari R: Decoy oligodeoxynucleotides targeting NF-kappaB transcription factors: induction of apoptosis in human primary osteoclasts. Biochem Pharmacol 66: 1189-1198, 2003. 
50. Vinayak R, van der Laan AC, Brill R, Otteson K, Andrus A, Kuyl-Yeheskiely E and van Boom JH: Automated chemical synthesis of PNA and PNA-DNA chimera on a nucleic acid synthesizer. Nucleosides Nucleotides 16: 1653-1656, 1997.

51. Mischiati C, Borgatti M, Bianchi N, et al: Interaction of the human NF-kappaB p52 transcription factor with DNA-PNA hybrids mimicking the NF-kappaB binding sites of the human immunodeficiency virus type 1 promoter. J Biol Chem 274: 33114-33122, 1999.

52. Mischiati C, Borgatti M, Feriotto G, Rutigliano C, Breda L, Bianchi N and Gambari R: Inhibition of HIV-1 LTR-driven in vitro transcription by molecular hybrids based on peptide nucleic acids mimicking the NF-kappaB binding site. Int J Mol Med 9: 633-639, 2002.

53. Matsuzaki K, Katayama K, Takahashi Y, Nakamura I, Udagawa N, Tsurukai T, Nishinakamura R, Toyama Y, Yabe Y, Hori M, Takahashi N and Suda T: Human osteoclast-like cells are formed from peripheral blood mononuclear cells in a coculture with SaOS-2 cells transfected with the parathyroid hormone (PTH)/PTH-related protein receptor gene. Endocrinology 140: 925-932, 1999.

54. Villanova I, Townsed PA, Uhlmann E, Knolle J, Peyman A, Amling M, Baron R, Horton MA and Teti A: Oligodeoxynucleotide targeted to the av gene inhibits integrin synthesis, impairs oteoclast function, and activates intracellular signals to apoptosis. J Bone Miner Res 14: 1867-1879, 1999.
55. Penolazzi L, Lambertini E, Aguiari G, Del Senno L and Piva R: Cis element 'decoy' against the upstream promoter of the human estrogen receptor gene. Biochim Biophys Acta 1492: 560-567, 2000 .

56. Penolazzi L, Lambertini E, Aguiari G, Del Senno L and Piva R: Modulation of estrogen receptor gene expression in human breast cancer cells: a decoy strategy with specific PCRgenerated DNA fragments. Breast Cancer Res Treat 49: 227$235,1998$.

57. Piva R, Del Senno L, Lambertini E, Penolazzi L and Nastruzzi C: Modulation of estrogen receptor gene transcription in breast cancer cells by liposome delivered decoy molecules. J Steroid Biochem Mol Biol 75: 121-128, 2000

58. Lambertini E, Penolazzi L, Aguiari G, Del Senno L, Pezzetti F, Sollazzo V and Piva R: Osteoblastic differentiation induced by transcription factor decoy against estrogen receptor alpha gene. Biochem Biophys Res Commun 292: 761-770, 2002.

59. Nielsen PE, Egholm M, Berg RH and Buchardt O: Sequenceselective recognition of DNA by strand displacement with a thymine-substituted polyamide. Science 254: 1497-1500, 1991.

60. Saviano M, Romanelli A, Bucci E, Pedone C, Mischiati C, Bianchi N, Feriotto G, Borgatti M and Gambari R: Computational procedures to explain the different biological activity of DNA/ DNA, DNA/PNA and PNA/PNA hybrid molecules mimicking NF-kappaB binding sites. J Biomol Struct Dyn 18: 353-362, 2000 . 